\title{
HYSTERESIS AND THERMAL INERTIA OF SPHERES OF ALTERNATIVE MATERIALS FOR BLACK GLOBE THERMOMETERS
}

\author{
Carlos A. de P. Sampaio ${ }^{1 *}$, Rodrigo F. Terezo ${ }^{1}$, Ilson Vassem Júnior ${ }^{1}$, \\ Leonardo M. da C. Silva ${ }^{1}$, Luiza K. Borges ${ }^{1}$
}

\author{
1* Corresponding author. Universidade do Estado de Santa Catarina - CAV/ UDESC/ Lages - SC, Brasil. \\ E-mail: carlos.sampaio@udesc.br | ORCID ID: https://orcid.org/0000-0003-3931-3840
}

\section{KEYWORDS}

thermal comfort, instrumentation, thermal properties, radiant temperature.

\begin{abstract}
This research was conducted with the objective of evaluating the thermal inertia and hysteresis of the following materials in a wind tunnel: hollow copper sphere with 150.0 $\mathrm{mm}$ diameter used as standard in globe thermometers, hollow brass sphere with $75.0 \mathrm{~mm}$ diameter, and two hollow plastic spheres with 115.5 and $69.7 \mathrm{~mm}$ diameter. The results showed that the thermal inertia and hysteresis for the hollow copper sphere were approximately 24 and $28 \mathrm{~min}$, respectively; these values were bigger than those obtained for the other spheres, implying faster responses of these. While there were no statistical differences in the measurements conducted by globe thermometers which are used to indicate the black globe temperature with the different types of spheres mentioned above under indoor environment conditions, i.e., with no wind and solar radiation, the wind causes faster cooling in smaller spheres under outdoor environment conditions, which may denote erroneous interpretations of the measurements at those instants. It was concluded that it is possible to replace the hollow copper sphere of diameter $150 \mathrm{~mm}$ by other types of spheres to measure the black globe temperature. However, this requires knowledge of the response times of the spheres as well as corrections to be made in the measurements with respect to the globe thermometer standard.
\end{abstract}

\section{INTRODUCTION}

The black globe thermometer is an environment energy receiver, widely used to assess the effects of radiant and convective heat transfer on humans and animals. Measurements conducted by the black globe thermometer combine the effects of radiant energy from the sun and neighboring surfaces, temperature and air velocity to assess the effective environmental temperature.

This instrument has been used in studies on dairy, beef cattle, swine, equine and poultry (Rojas-Downing et al., 2017; Tavares et al., 2016; Carneiro et al., 2015; Pérez et al., 2015; Silva et al., 2015; Nascimento et al., 2014; Neto \& Nääs, 2014; Rosselle et al., 2014; Purswell \& Davis, 2008) as well as in studies on humans (Saliba \& Lanza, 2016; Oliveira Júnior et al., 2015; NR-15 (MTE, 1978).

The ISO standard 7726/1996 describes the use of the globe thermometer to determine the average radiant temperature, as its spherical shape presents an approximation of the shape of the human body in the case of a person sitting repose. Theoretically, the black globe may have any diameter, however, the present standard is
$0.15 \mathrm{~m}$. The standard black globe - Vernon's globe -consists of a hollow metallic sphere of internal diameter $0.15 \mathrm{~m}$ and variable thickness (approximately $0.5 \mathrm{~mm}$ ), and it is painted matte-black for maximum absorptivity in the infrared region of the solar spectrum. The black globe temperature is obtained by a thermometer inserted into the globe up to the center of the sphere, which presents a manifestation of the thermal balance that occurs within the sphere between the heat gained (or lost) by radiation and the heat lost (or gained) by convection.

Souza et al. (2002) evaluated three black globes made of plastic polyvinyl chloride (PVC) with diameters of 15.0, 11.5 and $3.6 \mathrm{~cm}$; one black globe made of aluminum with a diameter of $13.0 \mathrm{~cm}$; one black globe made of brass with a diameter of $9.0 \mathrm{~cm}$, and compared them with a black globe made of copper with a diameter of $13.5 \mathrm{~cm}$ using the BGHI (Black Globe Humidity) and RTL (Radiant Thermal Load) indexes. They concluded that the PVC globes (of diameters 15.0 and $11.5 \mathrm{~cm}$ ) presented the best balance between cost and benefit. However, in this study, the thermal inertia and hysteresis of the globes were not evaluated.

${ }^{1}$ Universidade do Estado de Santa Catarina - CAV/ UDESC/ Lages - SC, Brasil.

Received in: 10-18-2018

Accepted in: 6-26-2019 
Moraes et al. (2011) evaluated a plastic lamp and a ping-pong ball for use as an alternative to the black globe thermometer standard. They concluded that these may be used in the field to replace the globe thermometer standard with reliable results and cost-effectiveness. In this study as well, the thermal inertia and hysteresis of the globes were not evaluated.

Coelho et al. (2013) compared seven alternative materials for black globes with the globe thermometer standard. They concluded that the alternative materials could be used in place of the copper globe and recommended that, based on the material used, a correction must be made before using the black globe thermometer in the calculation of black globe humidity and radiant thermal load indexes. In this study as well, the thermal inertia and hysteresis of the globes were not calculated.

Most studies conducted with black globe thermometers evaluate their ability to indicate thermal comfort. However, they do not measure the response time of the sphere being used correctly. A hollow sphere made of alternative materials is more affordable compared to the hollow copper sphere used in the standard black globe thermometer.

The objective of this research was to evaluate the thermal inertia and hysteresis of the following materials: hollow copper sphere, hollow brass sphere, and two hollow plastic spheres under controlled conditions of temperature and air velocity, enabling analysis by heating and cooling as well as by comparing the measurements of the black globe temperature conducted using these spheres.

\section{MATERIAL AND METHODS}

This study was conducted in the Laboratory of Ambience - CAV/UDESC located on the campus of Lages, Santa Catarina. The geographical coordinates are $27^{\circ} 49^{\prime}$ latitude South and 50 20' longitude East. The average altitude is $940 \mathrm{~m}$. The climate according to the Köppen Climate Classification System is Cfb (mesothermic humid).

The black spheres evaluated were designated as follows:

Ssta: hollow copper sphere with $150.0 \mathrm{~mm}$ diameter (used in the standard black globe thermometer); $V_{\text {sphere }} / A_{\text {sphere }}=$ |25.00|. Where $V$ refer to the volume and $A$ refer to superficial area of the sphere.

Sbco: hollow brass sphere with $75.0 \mathrm{~mm}$ diameter (used in commercially available black globe thermometer instruments); $V_{\text {sphere }} / A_{\text {sphere }}=|12.50|$.

Spbw: hollow plastic sphere/spherical buoy with $115.1 \mathrm{~mm}$ diameter (which is being considered as an alternative for the black globe thermometer); $V_{\text {sphere }} / A_{\text {sphere }}=|11.53|$

Spbp: hollow plastic sphere/plastic ball found in amusement parks with $69.7 \mathrm{~mm}$ diameter (which is being considered as an alternative for the black globe thermometer); $V_{\text {sphere }} / A_{\text {sphere }}=|11.62|$

For the determination of the thermal inertia and hysteresis of the spheres, a wind tunnel with the dimensions of $40 \mathrm{~cm} \times 40 \mathrm{~cm}$ and $120 \mathrm{~cm}$ length was built by installing a fan-heater of air at one end and the black spheres at the opposite end, as shown in Figure 1. The wind tunnel was designed to produce a steady and unidirectional airflow.

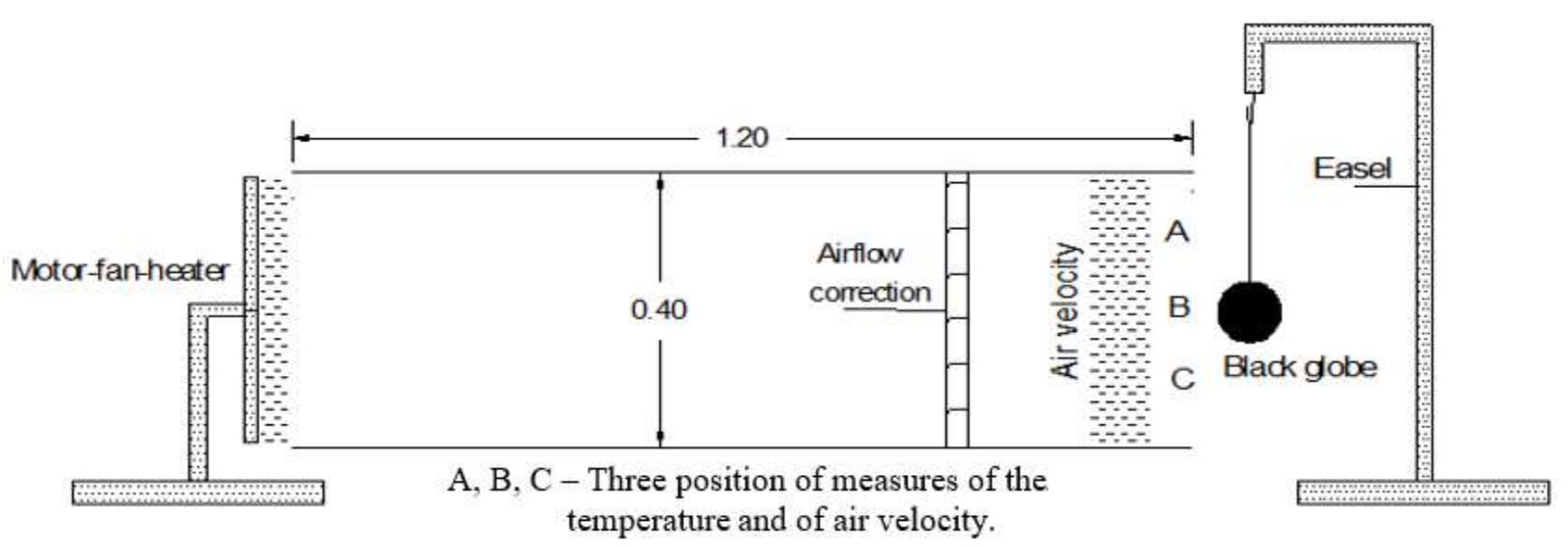

FIGURE 1. Wind tunnel designed to measure the temperature and air velocity of spheres.

The measurements were conducted upon alternately heating and cooling of the black globes spheres in oneminute intervals. Three air velocities, i.e., 0.75, 1.25 and $1.75 \mathrm{~m} . \mathrm{s}^{-1}$, were used and three sets of measurements were obtained for each air velocity. The choice of these velocities simulated those that naturally occur on a calm day.

The heating process was terminated when the maximum temperature stabilized after at least 10 repetitions of the same measurement, which was variable based on the velocity of attack of the air on the spheres. This process was used to define the thermal inertia of the spheres. For the cooling process, the heating and ventilation system was switched off. This process was used to define the hysteresis of the spheres.
To avoid conflict between the measurements of hysteresis and thermal inertia, the heating was always stopped after $30 \mathrm{~min}$. Further, the two parameters were determined only upon stabilization after repeated measurements.

The air velocities in the wind tunnel were measured using a portable digital thermo-anemometer (Itan-720) with an air velocity scale between 0.4 and $45.0 \mathrm{~m} . \mathrm{s}^{-1}$, accuracy of $\pm 3 \%+0.2 \mathrm{~m} . \mathrm{s}^{-1}$ and resolution of $0.1 \mathrm{~m} . \mathrm{s}^{-1}$. The variation in the temperatures of the air and the black spheres in the wind tunnel were determined using a mercury thermometer with scale between -10 and $+60{ }^{\circ} \mathrm{C}$ and resolution of $1{ }^{\circ} \mathrm{C}$. To measure the temperature of the spheres, the mercury thermometer was inserted up to the centers of the spheres. 
The hysteresis and thermal inertia of the spheres determined in the wind tunnel were used to define the black globe temperature $\left(T_{\mathrm{bg}}\right)$ considering a sphere of $15 \mathrm{~cm}$ diameter as standard. These measurements were performed under field conditions at hourly intervals, from 10 am to 5 $\mathrm{pm}$, to characterize the errors between the readings and their possible causes. Thus, the black globe thermometers were evaluated under indoor environment conditions, i.e., without any wind or solar radiation, for three consecutive days, placed at a height of $1.50 \mathrm{~m}$ from the floor. Thereafter, they were evaluated under outdoor environment conditions, i.e., with wind and solar radiation, for five alternate days, placed at a height of $1.50 \mathrm{~m}$ from the grassy surface. The air velocities and temperatures and black globe temperatures $\left(T_{\mathrm{bg}}\right)$ were measured with the same instruments used for the wind tunnel measurements. However, the air temperature was determined using a sling psychrometer (rotating handle).

The hysteresis and thermal inertia were defined in function of the repetition of measurements and by the sensitivity in the definition of this value after three repetitions for each velocity. For the internal and external environment, the statistical analysis method used was randomized block design (DBC) and black globe thermometers with four types of spheres -BG-Ssta, BG-Sbco, BG-Spbw and BG-Spbp - were tested, being the days as the repetitions. The response variable was the black globe temperature $\left(T_{\mathrm{bg}}\right)$ and the schedules, the blocks. The analysis of variance F-test and the Tukey test at 5\% probability were used for the comparison of averages.

\section{RESULTS AND DISCUSSION}

Figure 2 shows the graphs of the temperature in ${ }^{\circ} \mathrm{C}(y$ axis) versus schedule in minutes ( $x$-axis) for the four spheres: Ssta, Sbco, Spbw and Spbp obtained from the test conducted in the wind tunnel for the determination of the response time. The type of sphere in use is specified in the graphs.

In the graphs, the term "Ida" refers to the amount of time for which the spheres were subjected to heating until temperature stabilization and the term "Volta" refers to the cooling behavior of the spheres until temperature stabilization.

The graphs show similar behavior for all spheres, with the maximum heating achieved as a function of the velocity of the heated air. The $V_{\text {sphere }} / A_{\text {sphere }}$ relation is valid because its largest value represents high thermal inertia and its lowest value represents faster heating at the beginning.

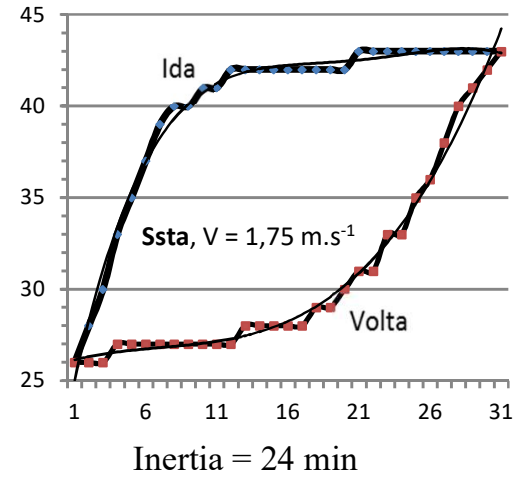

Hysteresis $=28 \mathrm{~min}$

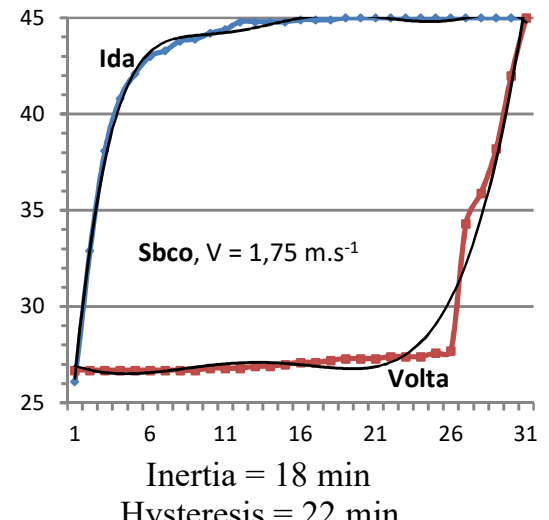

Hysteresis $=22 \mathrm{~min}$

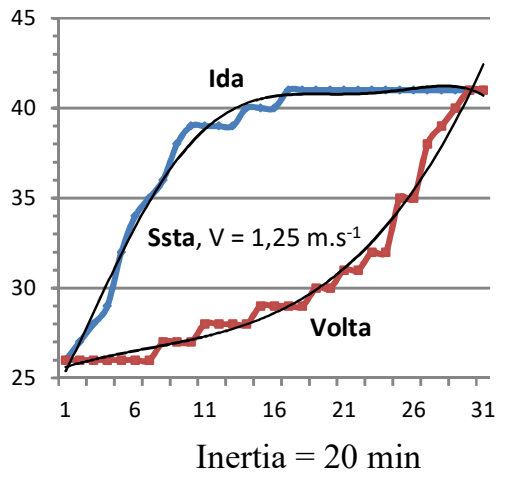

Hysteresis $=25 \mathrm{~min}$

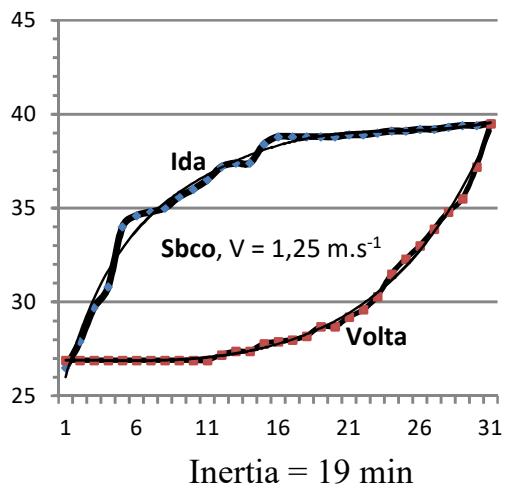

Hysteresis $=22 \mathrm{~min}$

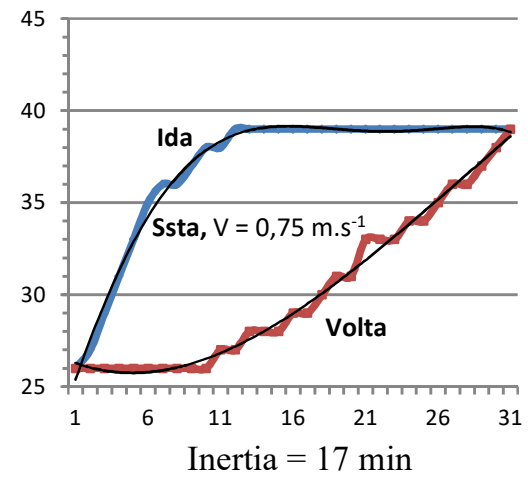

Hysteresis $=20 \mathrm{~min}$

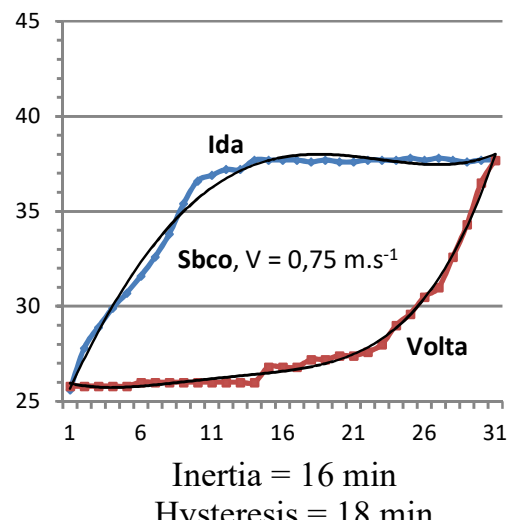

Hysteresis $=18 \mathrm{~min}$ 


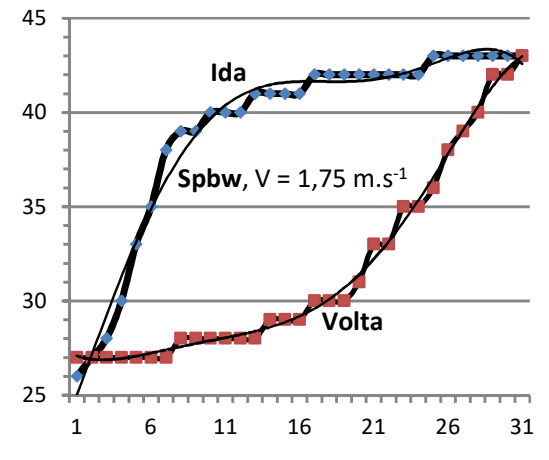

Inertia $=23 \mathrm{~min}$

Hysteresis $=26 \mathrm{~min}$

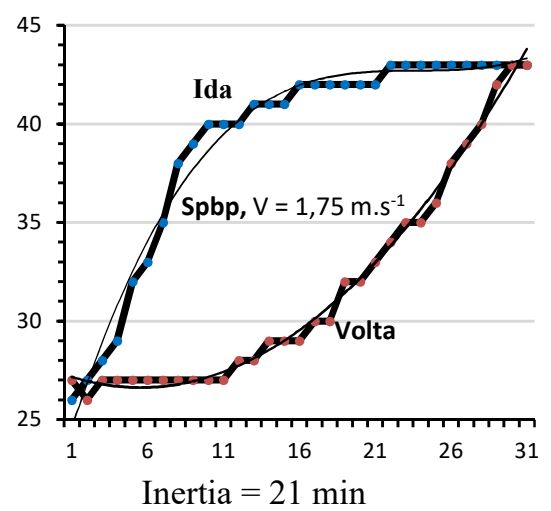

Hysteresis $=23 \mathrm{~min}$

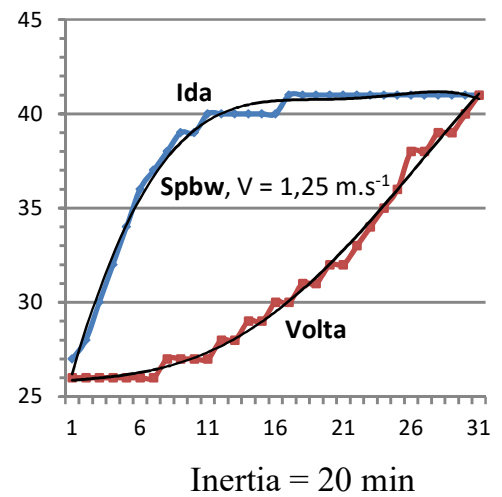

Hysteresis $=24 \mathrm{~min}$

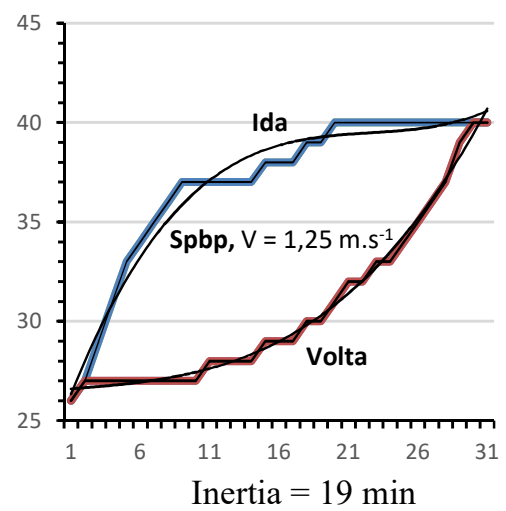

Hysteresis $=21 \mathrm{~min}$

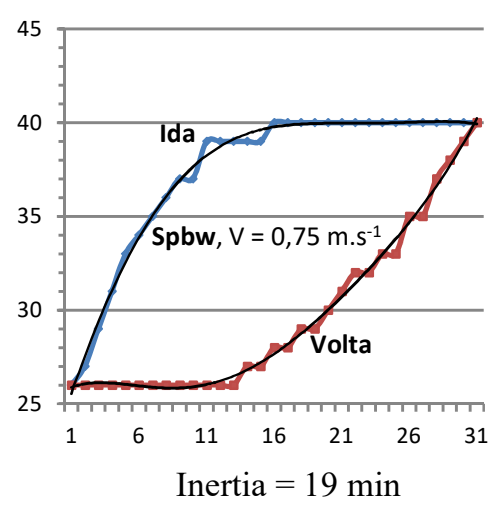

Hysteresis $=20 \mathrm{~min}$

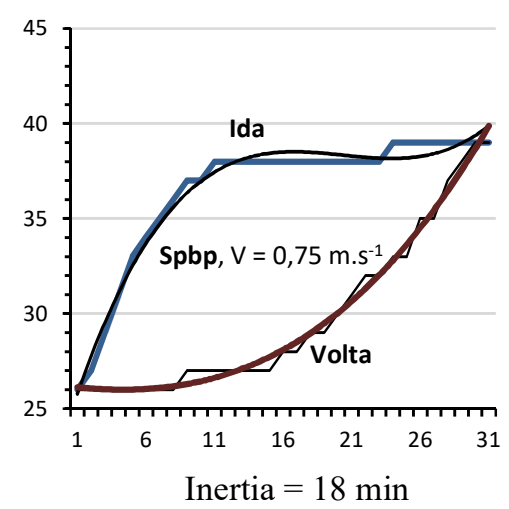

Hysteresis $=19 \min$

FIGURE 2. Behavior of spheres upon heating and cooling in the wind tunnel.

The thermal inertia was related mainly with the diameters and materials of the globes (ISO 7726/1996), but also with the velocity of the heated air. The values of thermal inertia were approximately 24, 20, and $17 \mathrm{~min}$ for the hollow copper sphere; 19,18 , and 16 min for the hollow brass sphere; 23, 20, and 19 min for the hollow plastic sphere with $115.5 \mathrm{~mm}$ diameter; and 21, 19, and 18 min for the hollow plastic sphere with $69.7 \mathrm{~mm}$ diameter, related to the air velocity of $1.75,1.25$ and $0.75 \mathrm{~m} \cdot \mathrm{s}^{-1}$, respectively.

For hysteresis, it was found that it required a long time for the spheres to reach the initial temperature by cooling and the condition was rarely achieved, i.e., the heat gain was faster than the heat loss. The values of hysteresis for the hollow copper sphere were approximately 28,25 and 20 min with respect to air velocities of $1.75,1.25$ and 0.75 $\mathrm{m} . \mathrm{s}^{-1}$, respectively, and these values agree with the recommendations of ISO 7726/1996. The values obtained were approximately 22,22 , and $18 \mathrm{~min}$ for the hollow brass sphere; approximately 26,24 , and $20 \mathrm{~min}$ for the hollow plastic sphere with $115.5 \mathrm{~mm}$ diameter and approximately 23, 21, and 19 min for the hollow plastic sphere with 69.7 $\mathrm{mm}$ diameter with respect to the air velocity of $1.75,1.25$ and $0.75 \mathrm{~m} . \mathrm{s}^{-1}$, respectively.

Figure 3 shows the variation of the black globe temperature $\left(T_{\mathrm{bg}}\right)$ with respect to time under indoor environment conditions, i.e., without solar radiation and wind.

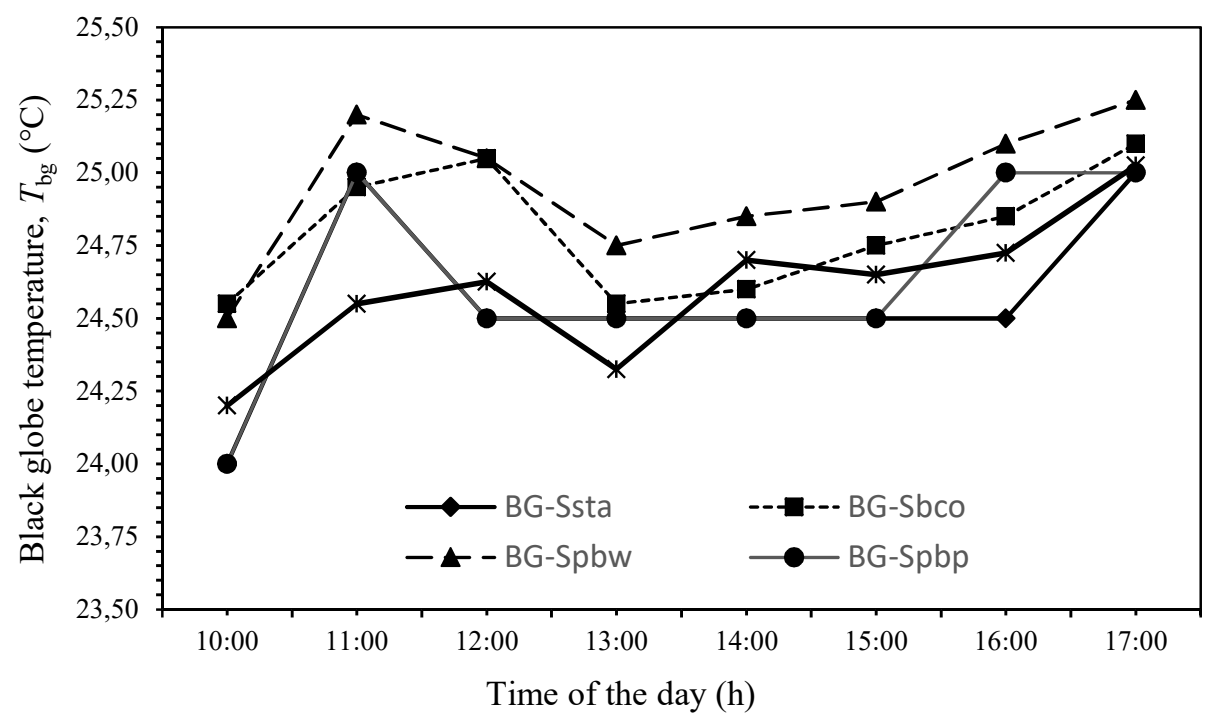

FIGURE 3. Graph of average $T_{\mathrm{bg}}$ vs schedule for black globe thermometers with different types of spheres evaluated as a function of air temperature $\left(T_{\text {air }}\right)$, under indoor environment conditions, i.e., without solar radiation and wind. 
Under these conditions, the globe thermometers presented small variations, of less than $1.0{ }^{\circ} \mathrm{C}$, in the temperature. It was confirmed that the black globes with the evaluated spheres presented identical readings during the course of the day.

Figure 4 shows the variation of the black globe temperature $\left(T_{\mathrm{bg}}\right)$ with respect to schedule under outdoor environment conditions, i.e., with solar radiation and wind.

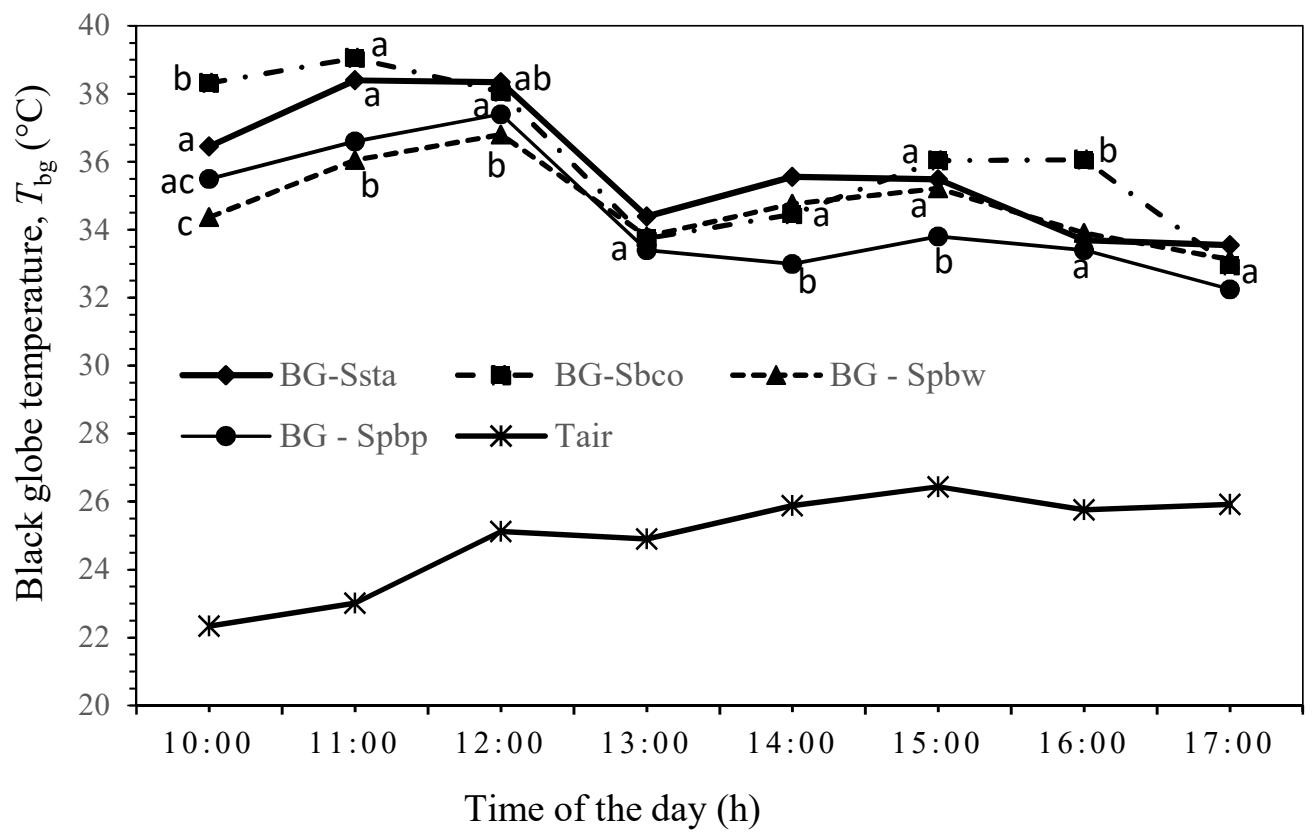

FIGURE 4. Graph of average $T_{\mathrm{bg}}$ vs schedule for black globe thermometers with different types of spheres evaluated as a function of air temperature $\left(T_{\text {air }}\right)$, under outdoor environment conditions, i.e., with solar radiation and wind.

The statistical analysis based on schedule using the Tukey test is shown in the graph, in which the average, denoted by the same letters, at the same moment of measurement, does not differ by more than 5\%.

It can be verified that the black globe measurements follow a similar behavior with respect to external air temperature variations. There were no statistical differences among the black globe measurements only at $1 \mathrm{pm}$ and 5 pm. The measurements conducted by BG-Sbco (commercially available black globe thermometer instrument with digital display) differed statistically from those of the black globe standard (BG-Ssta) at 10 am and 4 $\mathrm{pm}$. The other alternatives to the black globe thermometer, i.e., those formed by spheres of plastic (BG-Spbw and BGSpbp), provide different measurements from the standard at various times. Under turbulent wind conditions, the black spheres Sbco, Spbw and Spbp cool faster compared to Ssta, which could lead to erroneous interpretations and readings for the analysis if the measurements are conducted at that moment.

Much of this analysis of the measurements of $T_{\mathrm{bg}}$, in particular, the different response times, can be related only with the thermal inertia and hysteresis of the spheres, variables obtained at temperature and velocity of the air controlled. Hysteresis is the ability of a body to preserve a deformation effected by a stimulus and thermal inertia is the ability of a material to store heat and to restore slowly. These parameters define the response time of the sensors the sensors do not change the state of their output immediately; it requires some time for them to reach $100 \%$ of the variation that they finally present.
Comparing and contrasting the measurements conducted by the standard black globe thermometer, assuming it to be a reference point, the correction of the values measured by the other spheres is necessary. Similar results were obtained by Coelho et al. (2013), Moraes et al. (2011), and Souza et al. (2002). These values also agree with the indications of ISO 7726/1996.

\section{CONCLUSIONS}

When assessed in the wind tunnel, black spheres of different materials and diameters presented different response times, as indicated by the determination of thermal inertia and hysteresis. The hysteresis using the copper sphere of $15 \mathrm{~cm}$ diameter as reference was evaluated as $28 \mathrm{~min}$.

Under indoor environmental conditions, i.e., with no wind and solar radiation, no statistical differences were found among the measurements conducted by the black globe thermometers formed by the different types of spheres evaluated. However, under outdoor environment conditions, i.e., with wind blowing in different directions, the momentary measurements conducted using the different black spheres can cause erroneous interpretations and analyses of the results. To alleviate this situation, it is recommended that the same black globe thermometer (with identical diameters and materials) be used for measurements under different conditions.

The substitution of the sphere of the standard black globe thermometer made of copper by spheres of different diameters and materials to measure the black globe temperature $\left(T_{\mathrm{bg}}\right)$ is possible, although essentially with an adjustment of values. 


\section{REFERENCES}

Carneiro TA, Guiselini C, Pandorfi H, Lopes Neto JP, Lopes V, Souza RFL (2015) Primary thermal conditioning of rural installations by means of different types of cover. Revista Brasileira de Engenharia Agrícola e Ambiental 19(11):1086-1092. DOI: http://dx.doi.org/10.1590/18071929/agriambi.v19n11p1086-1092/2016

Coelho RB, de Paula MO, Ramirez MA, Caetano SP, Vieira DFD (2013) Estudo de materiais alternativos empregados na confecção do termômetro de globo negro utilizado para cálculo de ITGU e CTR. Engenharia na Agricultura 21(6). DOI: http://dx.doi.org/10.13083/14143984.v21n06a07/2013

ISO 7726 (1996) Ergonomics of the thermal environment - Instruments for measuring physical quantities. ISO

MTE - Ministério do Trabalho e Emprego. Portaria 3.214 de 1978. Normas regulamentadoras de segurança e saúde no trabalho (NR-15): Atividades e Operações Insalubres. Brasília. Available: http://www.mte.gov.br/temas/segsau/legislacao. Accessed: Jun 15, 2015.

Moraes SRP, Oliveira ALR, Simão PS, Rodrigues JS (2011) Eficiência bioclimatológica dos termômetros construídos com luminária plástica e bola de pinguepongue, em comparação ao globo negro padrão - outono e primavera. Enciclopédia Biosfera 7(12).

Nascimento GR, Nääs IA, Baracho MS, Pereira DF, Neves DP (2014) Termografia infravermelho na estimativa de conforto térmico de frangos de corte. Revista Brasileira de Engenharia Agrícola e Ambiental 18(6):658-663.

Neto MM, Nääs IA (2014) Software de agricultura de precisão para monitorar aspectos ambientais de conforto térmico na bovinocultura de leite. Brazilian Journal of Biosystems Engineering 8(2):112-127.
Oliveira Júnior AJ, Souza SRL, Barros ZX, Sartori MMP, Franco LV (2015) Índice de desconforto e índice de temperatura efetiva: uma implementação para smartphones e tablets. Revista Energia na Agricultura 30(2):155-163.

Pérez G, Vila A, Solé C, Coma J, Castell A, Cobeza LF (2015) The thermal behavior of extensive green roofs under low plant coverage conditions. Energy Efficiency 8:881-894.

Purswell JL, Davis JD (2008) Construction of a low-cost black globe thermometer. American Society of Agricultural and Biological Engineers 24(3):379-381.

Rojas-Downing MM, Nejadhashemi AP, Harrigan T, Woznicki SA (2017) Climate change and livestock: Impacts, adaptation, and mitigation. Climate Risk Management 16:145-163.

Rosselle L, Permentier L, Verbeke G, Driessen BR, Geers $R$ (2014) Interactions between climatological variables and sheltering behavior of pastoral beef cattle during sunny weather in a temperate climate. Journal of Animal Science 91:943-949.

Saliba TM, Lanza MBF (2016) Estratégia de avaliação dos riscos ambientais: tratamento estatístico dos dados. São Paulo, LTR, 115p.

Silva MG, Martin S, Oliveira CEG, Moscon ES, Damasceno FA (2015) Desempenho térmico de tipos de coberturas no interior de modelos reduzidos de galpões avícolas. Energia na Agricultura 30(3):269-275.

Souza CF, Tinôco IFF, Baêta FC, Ferreira WPM, Silva RS (2002) Avaliação de materiais alternativos para confecção do termômetro de globo. Ciência e Agrotecnologia 26(1):157-164.

Tavares GF, Carnevskis EL, Schiassi L, Filho RC, Miranda KOS, Miranda JH (2016) Zoneamento bioclimático para bovinos de corte no Brasil com o auxílio de sistemas inteligentes. Journal of Animal Behavior and Biometeorology 4(4):116-123. 